\title{
Effect of Protein Supplements on Renal Function and Lipid Profile
}

Rehab M. El-Gharabawy 1,2, Amira S. Ahmed 1,3, Afnan I. Alawad ${ }^{4}$

\section{Abstract}

Background: Protein supplements are one of the most frequently dietary supplements used by athletes and non-athletes in Saudi Arabia.

Objective: To assess the knowledge, attitude and practice of Saudi population toward the protein supplements, examine the relationships of practice with education level, effect of protein on kidneys and lipid profile, assess the types and source of protein supplements, assess the correct use of protein supplements according to exercise intensity and determine protein content and heavy metals in protein supplements.

Methods: A national cross-sectional survey was conducted during October-December 2017 on protein supplements users in Saudi Arabia. Moreover, samples of the best selling protein supplements were analyzed to determined total protein and heavy metals content.

Results: A total of 398 filled protein supplements user questionnaire. The wrong practice of use associated with the effect of protein supplements on renal function and lipid profile. The percentage of protein content in isolated whey protein $(68.18 \%)$ whiles by Kjeldhl analysis $(80.55 \%)$. Concentrated whey protein contain $(72 \%)$ and by kjeldhl analysis (77.2\%). Hydrolyzed collagen containing (100\%) protein and by kjeldhl analysis (91.25\%).The amount of heavy metals in isolated whey protein contains arsenic $(83 \mu \mathrm{g} / \mathrm{kg})$, mercury $(<10 \mu \mathrm{g} / \mathrm{kg})$ and lead $(18 \mu \mathrm{g} / \mathrm{kg})$, while hydrolyzed collagen sample contains arsenic $(101 \mu \mathrm{g} / \mathrm{kg})$, mercury $(<10 \mu \mathrm{g} / \mathrm{kg})$ and lead $(49 \mu \mathrm{g} / \mathrm{kg})$.

Conclusion: The current study reveals an evidence for lacking of the awareness, negative attitude and abuse of protein supplements, demonstrates necessity to further education regarding the use and purchasing of protein supplements to ensure the quality of these products. 


\section{Introduction}

Nutritional supplements are defined by United States law as products taken by oral to complete total daily requirements. It is increasing in use to $88 \%$ globally $[1,2]$.

Protein supplements are one of the most frequently used dietary supplements used by athletes and non-athletes $[3,4]$. Recently whey protein and hydrolyzed collagen have seen heavy marketing. Many people are making them a part of their diet and exercise routines [5].

Collagen is a main structural protein, which is extracted from collagen-rich materials with hot water as gelatin. The common materials used for extracting gelatin include bovine, bones and fish. The further enzymatic hydrolysis of gelatin results in hydrolyzed collagen [6]. Hydrolyzed collagen contains all amino acids necessary to retain the normal structure and strength of the skin, connective tissues, tendons, cartilage, bones and joints [7, 8].

Milk is made up of two types of protein: casein and whey. Whey is the liquid portion of milk that can be extracted and separated from casein or it can be formed as a by-product when cheese is being made [9]. Whey is high use because of its ability to increase muscle mass and reduce body fat $[3,4,10]$. It is extracted, purified and separated to obtain several concentrations that also vary in fat and carbohydrate. Three main forms of whey protein are: concentrate, isolate and hydrolyzed whey protein. Concentrate whey protein contains about (89\%) protein and (10\%) fat. Filtering this (89\%) protein removes more carbohydrate, lactose and fat, and this creates isolate whey protein which has protein at more than (90\%) and less fat (0.5\%). Hydrolyzed whey protein is fraction to small peptides variable in protein and fat content $[5,9]$.

There is an expectation by consumers the protein supplements that they will meet their dietary and health needs by ingestion of these supplements. There is a belief that the stated amounts of the ingredients contained in them are pure and do not contain any foreign ingredients other than the ones listed on the label of the containers. However, research has proven that, these supplements can be contaminated with impurities. There is an evidence of poor quality control in the manufacture and preservation of these supplements [5].

After tests and research on some of commercially-available protein supplements products, they failed to pass the quality assurance test [11]. It was found that, protein powders and drinks contaminated with heavy metals(lead, arsenic, cadmium and mercury). The levels of the contamination were too high. Such a concentration is enough to pose great risk to consumers (5). It affects health of many organs like liver, kidneys, brain, heart and cause blood lipid profile disturbance [12]. The users should be informed regarding safety associated with Protein supplements and consider the quality of protein contained in the protein supplements and the possibility of adulteration [11].

Recently, they are increasing in interest and use in Saudi Arabia $[13,14]$. Approximately $68.4 \%$ of 316 participants had used protein supplements, and did not believe that these agents cause harm [15]. Additionally, Jawadi et al., (2017) study included 299 participants, who consume a total of 25 supplements, showed that the most common used supplements is whey protein (22.1\%) [14].

The Recommended Daily Allowance (RDA) of protein requirement forgeneral people is $0.8 \mathrm{~g} / \mathrm{kg} /$ day. This amount is adequate enough for general fitness or light exercise intensity, but the amount can still be raised to $1 \mathrm{~g} / \mathrm{kg} /$ day $[3,16]$. Increasing requirements with increase exercise intensity, for moderate exercise intensity $1.4 \mathrm{~g} / \mathrm{kg} /$ day and high volume of intensity $1.7 \mathrm{~g} / \mathrm{kg} /$ day according to the international society of sports nutrition (ISSN) [17]. The recommended daily amount of hydrolyzed collagen supplements is 10 grams [18].

It is recommended that the protein requirements should be reached through diet only [17]. On the 
other hand, if they intake protein supplement higher than recommended amount, they will be more susceptible to its side effects [19, 20].

High protein consumption may be deleterious on kidneys health [19]. The kidneys play a central role in balancing the effects of protein metabolism [21]. The increase in urea, albumin and calcium and oxalate excretion leads to hyper-filtration, which renders the kidneys more prone to chronic kidney disease (CKD) in healthy individuals and exacerbates issues in patients already suffering from kidney dysfunction [22, 23].

Most of these protein supplements contain creatine. creatine can develop interstitial nephritis which leads to renal failure. These side effects can be developed in a rather short period and even when taken as a small dosage $[23,24]$.

The increase in protein consumption is one of causes ofkidney stone disease and it's a risk factor of chronic kidney disease. This can be related to increase in acid excretion and lower renal $\mathrm{PH}$; which is caused by calcium, oxalate and urea excretion $[21,26]$.

Hydroxyproline is a non-essential amino acids (NEAA) mainly contained in collagen [27]. It gives strength to the protein collagen in bones, cartilage, tendons and skin, but there is a major risk factor involved in its consumption. It can lead to calcium oxalate stone formation which can end in renal failure $[23,26]$.

High intake of fruits and vegetables greatly reduces the risk of stone formation because of their high content of potassium and magnesium that helps in reduction urinary calcium excretion [21]. Constant exercise and high water intake at least two liters a day can protect kidneys and slow renal decline $[28,29]$.

As well, high protein consumption has a negative effect on blood lipid profile. It elevates low density lipoprotein (LDL) and triglyceride (TG) increasing risk of cardiovascular complications [30]. Intense and constant exercise can decrease this disturbance [31].
Therefore, there is a direct relationship between abuse of dietary protein supplements and the disturbance in renal function and lipid profile.

The aim of this study was to assess the knowledge, attitude and practice of Saudi population toward the protein supplements, to examine the relationships of practice with education level, effect of protein on renal function and lipid profile, to assess the types and source of protein supplements, to assess the correct use of protein supplements according to exercise intensity and to determine protein content and heavy metals in protein supplements.

\section{Materials and Method}

The study has two phases; including survey submitted to protein supplements users and determines protein content and heavy metals in protein supplements products collected from shops and purchased from Internet. The user's survey will investigate three parts: demographic data, usage protein supplements and perception of risk. Samples of the products sent to the laboratory for quantitative analyses.

\section{Inclusion criteria}

Saudi Arabian participants who are more than 13 years old and protein supplements users for at least 3 months were included in this study.

\section{Exclusion criteria}

Participants, who used protein supplements less than 3 months, are less than 13 years old or smokers and participants who has hypertension, renal, heart diseases before administration of protein supplements were excluded from this study.

\section{Study design}

A national cross-sectional, standardized and confidential survey was conducted on Saudi Arabian users of protein supplements during October-December, 2017 in Qassin region. 


\section{Data collection tool Questionnaire}

The questionnaire designed in English and later translated to Arabic by a professional translator and reviewed for consistency by the investigators. The questionnaire includes the demographics of protein supplements users, the source of getting protein supplements, the side effects related to protein supplements used and perception of the users to the associated risk. The questionnaire pre-test for validity, reliability and checked if it is easy for the interviewers to understand the instructions and flow of questions. Prior to pre-testing in the field, the interviewers undergo trainings and they provide with instructions about the survey.

\section{Measured correct quantity of protein supple- ments}

According to daily protein requirements for physical activity; general people without doing any exercise $(0.8 \mathrm{~g} / \mathrm{kg} /$ day $)$ general fitness $(1 \mathrm{~g} / \mathrm{kg} /$ day), moderate amount of intense training $(1.4 \mathrm{~g} / \mathrm{kg} /$ day $)$ and high volume of intense training $(1.7 \mathrm{~g} / \mathrm{kg} /$ day $)$ [11, $16,17]$. The recommendation for hydrolyzed collagen is $10 \mathrm{~g}$ per day [16].

\section{Chemical analysis}

Products collected from shops and online retailers were analyzed to determined total protein and heavy metals content. Determination of heavy metals content in protein supplements by inductively coupled plasma mass spectrometry (ICP-MS) and for total protein content using kjeldahl Method according to association of official analytical chemists AOAC methods (991.20) for whey protein samples and (981.10) for hydrolyzed collagen sample [32].

- Total protein content $=$ Total kjeldahl nitrogen x Conversion Factor (CF).

- CF: for whey protein samples (6.38).

- CF: for hydrolyzed collagen sample (5.58).

\section{Statistical analysis}

Data was analyzed using the (SPSS) version 24. Ascertain the significance of differences between mean values of two continuous variables was analyzed by t-test. Chi-Square test was used to determine associations between different variables. P-value $\leq 0.05$ will be considered significant.

\section{Results \\ Demographic characteristics}

The sample consisted of (398) Saudi Arabian participate in the study are shown in Table 1. (56.3\%) of the participants were in the age (21-30), while $(32.9 \%)$ of the participants were in the age (31-50) and $(10.3 \%)$ of the participants in the age (18-20) years.

The average weight of all participants was 70.92 $\mathrm{kg}$, and the average length of all participants was $164.62 \mathrm{~cm}$.

Two-thirds of the participants females (60.1\%), while $(39.9 \%)$ of males participated.

Table 1. Demographics characteristics $(n=398)$.

\begin{tabular}{|l|c|c|}
\hline \multicolumn{1}{|c|}{ Characteristics } & No. & $\%$ \\
\hline Age & 41 & 10.3 \\
\hline $13-20$ & 226 & 56.3 \\
\hline $21-30$ & 131 & 32.9 \\
\hline $31-50$ & & \\
\hline Gender & 239 & 60.1 \\
\hline Female & 159 & 39.9 \\
\hline Male & & \\
\hline Exercise intensity & 115 & 28.9 \\
\hline Don't exercise & 128 & 32.2 \\
\hline General fitness & 99 & 24.9 \\
\hline Moderate & 56 & 14.1 \\
\hline Strength & & \\
\hline Education level & 69 & 17.3 \\
\hline Intermediate or high school & 306 & 76.9 \\
\hline Bachelor & 23 & 5.8 \\
\hline Post graduated
\end{tabular}


One third of the participants (32.2\%) in general fitness, (28.9\%) don't exercise, (24.9\%) moderate intensity and (14.1\%) in Strength intensity.

Most of the participants had a bachelor's degree of $(76.9 \%)$ and $(17.3 \%)$ had Intermediate or high school while (5.8\%) had postgraduate studies.

\section{Types of protein supplements}

Table 2 shows that more than half of the participants $(51.8 \%)$ were taking isolated whey protein, while just over a quarter of the participants with (27.93\%) were taking concentrated whey protein, $(11.3 \%)$ of the participants were taking collagen and $(9 \%)$ of the participants were taking other protein supplements.

Table 2. Types of protein supplements $(n=398)$.

\begin{tabular}{|l|c|c|}
\multicolumn{1}{|c|}{ Characteristics } & No. & $\%$ \\
\hline What type of protein supplements do you use? & \\
\hline Isolated whey protein & 206 & 51.8 \\
\hline Concentrated whey protein & 45 & 11.3 \\
\hline Collagen & 111 & 27.9 \\
\hline Other & 36 & 9.0 \\
\hline
\end{tabular}

\section{Usage of protein supplements}

Table 3 shows that more than half (55\%) of the participants used protein supplements for bodybuilding, while (30.9\%) were taking protein supplements for cosmetic and (14.1\%) were taking protein supplements for other purposes.

Table 3. Usage of protein supplements $(n=398)$.

\begin{tabular}{|l|c|c|}
\multicolumn{1}{|c|}{ Characteristics } & No. & $\%$ \\
\hline What is the cause for using the protein supplements \\
\hline Bodybuilding & 219 & 55.0 \\
\hline Cosmetic & 123 & 30.9 \\
\hline Others & 56 & 14.1 \\
\hline Where did you get the protein supplements? & & \\
\hline Pharmacies & 77 & 19.3 \\
\hline Online & 186 & 46.7 \\
\hline Markets & 135 & 33.9 \\
\hline
\end{tabular}

On the other hand, (46.7\%) of participants got protein supplements online, while $(33.9 \%)$ of participants got it through markets and (19.3\%) got protein supplements through pharmacies.

\section{Knowledge about the risk related to protein supplements}

Table 4 shows that one hundred and fourteen (28.6\%) of our participants knew that the exceeding dose of protein supplements increase the side effect. Two hundred and thirty-two (58.3\%) of our participants knew that the protein supplements affect kidney. One hundred and seventeen (29.4\%) knew that the protein supplements affect lipid profile. Three hundred and nineteen (80.2\%) of our participantsknew that frequent drinking water may reduce the side effect. Two hundred and sixty-five $(66.6 \%)$ of our participants knew that exercise intensity may reduce the side effect.

Table 4. Knowledge about the risk related to protein supplements $(n=398)$.

\begin{tabular}{|l|c|c|}
\hline \multicolumn{1}{|c|}{ Characteristics } & No. & $\%$ \\
\hline $\begin{array}{l}\text { Does the exceeding dose of a protein } \\
\text { supplements increase the side effect? }\end{array}$ & 114 & 28.6 \\
$\begin{array}{l}\text { Do you think that protein supplements } \\
\text { affect kidney? }\end{array}$ & 232 & 58.3 \\
\hline $\begin{array}{l}\text { Do you think that protein supplements } \\
\text { affect lipid profile? }\end{array}$ & 117 & 29.4 \\
\hline $\begin{array}{l}\text { Do you think that frequent drinking water } \\
\text { may reduce the side effect? }\end{array}$ & 319 & 80.2 \\
\hline $\begin{array}{l}\text { Do you think that exercise intensity may } \\
\text { reduce the side effect? }\end{array}$ & 265 & 66.6 \\
\hline
\end{tabular}

\section{Attitude towards protein supplements use}

Figure 1 shows about (86\%) of participants took protein supplements without any advice from doctor or pharmacist, while about (14\%) of the participants took protein supplements with taking advice. 
Figure 1: Attitude towards protein supplements use $(n=398)$.

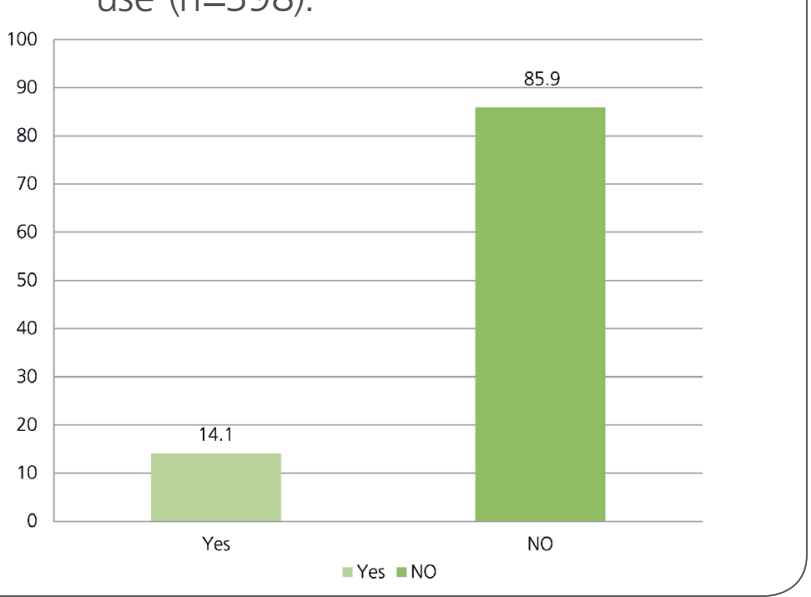

\section{Practice of protein supplements users}

Table 5 shows (43\%) of participants were taking protein supplements daily, (30.7\%) were taking them four to six times, while $(26.4 \%)$ were taking them once to three times. About (54.3\%) of parti-

Table 5. Practice of protein supplements users $(n=398)$

\begin{tabular}{l|c|c|}
\multicolumn{1}{|c|}{ Characteristics } & No. & $\%$ \\
\hline How many times do you use protein supplement per week? \\
\hline Daily & 171 & 43.0 \\
\hline four to six times & 122 & 30.7 \\
\hline Once to three times & 105 & 26.4 \\
\hline How to use protein supplements & & \\
\hline Correct & 216 & 54.3 \\
\hline Wrong & 182 & 45.7 \\
\hline How long have you been consuming your current protein & \\
\hline supplement? & & \\
\hline$\geq 3-6$ months & 198 & 49.7 \\
\hline More than 6 months & 57 & 14.3 \\
\hline Year & 46 & 11.6 \\
\hline More than year & 97 & 24.4 \\
\hline How much of water do you drink per day? & & \\
\hline 1-4 cups & 115 & 28.9 \\
\hline 4-6 cups & 132 & 33.1 \\
\hline 6-8 cups & 93 & 23.4 \\
\hline More than8 cups & 58 & 14.6 \\
\hline
\end{tabular}

cipants the protein correctly, while $(45.7 \%)$ of the participants took the protein in the wrong way.

Approximately half of the participants (49.7\%) of participants took the protein supplements for ( $\geq$ 3-6 months), while (14.3\%) of them took it for (more than 6 months), (11.6\%) took the protein supplements for one year and (24.4\%) of participants took the protein supplements for more than a year. About (28.9\%) of the participants took 1-4 cups of water per day, (33.1\%) took 4-6 cups per day (23.4\%) took $6-8$ cupsper day and (14.6\%) of the participants took more than 8 cups per day.

\section{Relationship between practice and education level}

Table 6 demonstrates that, There is no significant relationship between education level of our participants and the frequent usage of protein supplement per week $\left(x^{2}=4.651, P=0.325\right)$.

Also, there is no significant relationship between education level of our participants and the method of protein consumption $\left(x^{2}=1.816, P=0.403\right)$.

There is no significant relationship between Education level of our participants and the duration of protein consumption $\left(x^{2}=7.473, P=0.279\right)$.

There is no significant relationship between Education level of our participants and the amount of water per day $\left(x^{2}=11.088, P=0.086\right)$.

\section{Relationship between exercise intensity and the method of protein consumption}

Table 7 shows that there is a significant relationship between exercise intensity and the method of protein consumption $\left(x^{2}=14.944\right.$, P-value $\left.=0.001\right)$ which means that the protein consumption method varies according to exercise intensity and therefore affects the method of protein consumption.

Table 8 shows that only eighty five (21.4\%) of our participants found change in RFT, while Twentyeight $(7.0 \%)$ of the participants found no change in RFT after using the protein supplements. 
Table 6. Relationship between practice and education level $(n=398)$.

\begin{tabular}{|c|c|c|c|c|c|}
\hline \multirow[b]{2}{*}{ Question } & $\begin{array}{c}\text { Education } \\
\text { level }\end{array}$ & No. & $\%$ & $\begin{array}{c}\text { Chi- } \\
\text { Square }\end{array}$ & \multirow[b]{2}{*}{ Df } \\
\hline & $\begin{array}{l}\text { Intermediate } \\
\text { or high } \\
\text { school }\end{array}$ & Bachelor & $\begin{array}{c}\text { Post } \\
\text { graduated }\end{array}$ & $x^{2}$ & \\
\hline
\end{tabular}

How many times do you use protein supplement per week?

\begin{tabular}{l|l|l|l|l|l|l|}
\hline $\begin{array}{l}\text { Daily } \\
\text { four to six }\end{array}$ & 26 & 132 & 13 & & \\
\hline $\begin{array}{l}\text { times } \\
\begin{array}{l}\text { Once to } \\
\text { three times }\end{array}\end{array}$ & 16 & 89 & 6 & 4.651 & 4 & 0.325 \\
\hline
\end{tabular}

How to use protein supplements?

\begin{tabular}{|l|l|l|l|l|l|l|}
\hline Correct & 34 & 167 & 15 & 1.816 & 2 & 0.403 \\
\hline Wrong & 35 & 139 & 8 & & & \\
\hline
\end{tabular}

How long have you been consuming your current protein supplement?

\begin{tabular}{|c|c|c|c|c|c|c|}
\hline $\begin{array}{l}\geq 3-6 \\
\text { months }\end{array}$ & 33 & 155 & 10 & \multirow{4}{*}{7.473} & \multirow{4}{*}{6} & \multirow{4}{*}{0.279} \\
\hline $\begin{array}{l}\text { More than } \\
6 \text { months }\end{array}$ & 9 & 45 & 3 & & & \\
\hline Year & 13 & 32 & 1 & & & \\
\hline $\begin{array}{l}\text { More than } \\
\text { year }\end{array}$ & 14 & 74 & 9 & & & \\
\hline
\end{tabular}

How much of water do you drink per day?

\begin{tabular}{l|l|l|l|l|l|l|}
\hline \begin{tabular}{l} 
1-4 cups \\
\hline $4-6$ cups
\end{tabular} & 23 & 86 & 6 & & & \\
\hline $6-8$ cups & 16 & 75 & 2 & 11.088 & 6 & 0.086 \\
\hline $\begin{array}{l}\text { More } \\
\text { than8 cups }\end{array}$ & 6 & 44 & 8 & & & \\
\hline
\end{tabular}

Table 7. Relationship between exercise intensity and the method of protein consumption $(n=398)$.

\begin{tabular}{|c|c|c|c|c|c|}
\hline \multirow{2}{*}{ Exercise intensity } & \multicolumn{2}{|c|}{$\begin{array}{l}\text { consumption } \\
\text { method }\end{array}$} & \multirow{2}{*}{$\begin{array}{c}\begin{array}{c}\text { Chi- } \\
\text { Square }\end{array} \\
x^{2}\end{array}$} & \multirow{2}{*}{ Df } & \multirow{2}{*}{ Sig. } \\
\hline & Correct & Wrong & & & \\
\hline \multicolumn{6}{|c|}{ How many times do you use protein supplement per week? } \\
\hline Don't exercise & 51 & 64 & \multirow{4}{*}{15.944} & \multirow{4}{*}{3} & \multirow{4}{*}{0.001} \\
\hline Light & 62 & 66 & & & \\
\hline Moderate & 64 & 35 & & & \\
\hline Strength & 39 & 17 & & & \\
\hline
\end{tabular}

Table 8. Percentage of participants who found a change in RFT after using the protein supplements $(n=113)$.

\begin{tabular}{|l|c|c|}
\multicolumn{1}{|c|}{ Characteristics } & No. & $\%$ \\
\hline Do you find any change in your RFT? & & \\
\hline Yes & 85 & 21.4 \\
\hline No & 28 & 7.0 \\
\hline
\end{tabular}

\section{Relationship between practice and the change in RFT}

Table 9 shows that there is no significant relationship between type of protein supplements and the change in $\operatorname{RFT}\left(\mathrm{x}^{2}=2.775, \mathrm{P}=0.428\right)$.

Table 9. Relationship between practice and the change in RFT $(n=113)$.

\begin{tabular}{|c|c|c|c|c|c|}
\hline \multirow[t]{2}{*}{ Question } & \multicolumn{2}{|c|}{$\begin{array}{c}\text { change in } \\
\text { RFT }\end{array}$} & $\begin{array}{c}\text { Chi- } \\
\text { Square }\end{array}$ & \multirow[t]{2}{*}{ Df } & \multirow{2}{*}{ Sig. } \\
\hline & yes & No & $x^{2}$ & & \\
\hline
\end{tabular}

What type of protein supplements do you use?

\begin{tabular}{|l|c|c|c|c|c|}
\hline Isolated whey protein & 49 & 21 & & \\
\hline Concentrate whey protein & 13 & 3 & & & \\
\hline Collagen & 17 & 3 & 2.775 & 3 & 0.428 \\
\hline Other & 6 & 1 & & \\
\hline
\end{tabular}

How many times do you use protein supplement per week?

\begin{tabular}{|c|c|c|c|c|c|}
\hline Daily & 55 & 12 & \multirow{3}{*}{8.936} & \multirow{3}{*}{2} & \multirow{3}{*}{$0.011 *$} \\
\hline four to six times & 22 & 7 & & & \\
\hline Once to three times & 8 & 9 & & & \\
\hline \multicolumn{6}{|c|}{ How to use protein supplements? } \\
\hline Correct & 31 & 20 & \multirow{2}{*}{10.394} & \multirow{2}{*}{1} & \multirow{2}{*}{$0.002^{* *}$} \\
\hline Wrong & 54 & 8 & & & \\
\hline
\end{tabular}

How long have you been consuming your current protein supplement?

\begin{tabular}{|l|l|l|l|l|l|}
\hline$\geq 3-6$ months & 10 & 8 & & & \\
\hline More than 6 months & 15 & 5 & & & \\
\hline Year & 19 & 3 & 5.331 & 3 & 0.149 \\
\hline More than year & 41 & 12 & & & \\
\hline
\end{tabular}

Exercise intensity

\begin{tabular}{|l|c|c|c|c|c|}
\hline Don't exercise & 33 & 3 & & \\
General fitness & 26 & 7 & 11.795 & 3 & 0.008 ** \\
\hline Moderate & 16 & 10 & & & \\
\hline Strength & 10 & 8 & & & \\
\hline
\end{tabular}




\begin{tabular}{|c|c|c|c|c|c|}
\hline \multirow[t]{2}{*}{ Question } & \multicolumn{2}{|c|}{$\begin{array}{c}\text { change in } \\
\text { RFT }\end{array}$} & \multirow{2}{*}{$\begin{array}{c}\begin{array}{c}\text { Chi- } \\
\text { Square }\end{array} \\
x^{2}\end{array}$} & \multirow[t]{2}{*}{ Df } & \multirow[t]{2}{*}{ Sig. } \\
\hline & yes & No & & & \\
\hline \multicolumn{6}{|c|}{ How much of water do you drink per day? } \\
\hline $1-4$ cups & 21 & 6 & \multirow{4}{*}{31.756} & \multirow{4}{*}{3} & \multirow{4}{*}{$0.00^{* * *}$} \\
\hline 4-6 cups & 49 & 4 & & & \\
\hline $6-8$ cups & 12 & 7 & & & \\
\hline More than8 cups & 3 & 11 & & & \\
\hline
\end{tabular}

There is a significant relationship between usage of protein per week and the change in RFT $\left(x^{2}=\right.$ 8.936, $P=0.011$.

There is a significant relationship between the appropriate use of protein consumption and the change in RFT ( $x^{2}=10.394, P=0.002$ ).

There is no significant relationship between the duration of protein consumption and the change in RFT ( $\left.x^{2}=5.331, P=0.149\right)$.

There is a significant relationship between Exercise intensity and the change in RFT $\left(x^{2}=11.795\right.$, $\mathrm{P}=0.008$ ).

There is a significant relationship between the amount of water per day and the change in RFT $\left(x^{2}=31.756, P=0.00\right)$, which mean that increase the consumption of water improve renal function.

\section{Type of lipid profile changes after using the protein supplements}

Table 10 demonstrates that only thirty-three (8.3\%) of our participants found change in lipid profile after they were taken the protein supplements, while thirty-eight (9.5\%) found no change lipid profile after using the protein supplements.

Only fifteen (3.8\%) of our participants found that they had an increase in total cholesterol, while eight (2.0\%) of the participants found that they had a decrease in total cholesterol after using the protein supplements.

Only nine (2.3\%) of our participants found that they had an increase in triglycerides, while
Table 10. Type of lipid profile changes after using the protein supplements $(n=71)$.

\begin{tabular}{|c|c|c|c|}
\hline \multicolumn{2}{|c|}{ Characteristics } & No. & $\%$ \\
\hline \multicolumn{4}{|c|}{ What type of protein supplements do you use? } \\
\hline \multicolumn{2}{|c|}{$\begin{array}{l}\text { Does the exceeding dose of a protein } \\
\text { supplements increase the side effect? }\end{array}$} & 114 & 28.6 \\
\hline \multicolumn{2}{|c|}{$\begin{array}{l}\text { Do you think that protein supplements affect } \\
\text { kidney? }\end{array}$} & 232 & 58.3 \\
\hline \multicolumn{4}{|c|}{ What type of protein supplements do you use? } \\
\hline \multicolumn{2}{|c|}{$\begin{array}{l}\text { Does the exceeding dose of a protein } \\
\text { supplements increase the side effect? }\end{array}$} & 114 & 28.6 \\
\hline \multicolumn{2}{|c|}{$\begin{array}{l}\text { Do you think that protein supplements affect } \\
\text { kidney? }\end{array}$} & 232 & 58.3 \\
\hline \multicolumn{4}{|c|}{ What type of protein supplements do you use? } \\
\hline type of lipid profile change & what is the change & No. & $\%$ \\
\hline \multirow{2}{*}{ Total cholesterol (TC) } & Increase & 15 & 3.8 \\
\hline & decrease & 8 & 2.0 \\
\hline \multirow{2}{*}{ Triglycerides (TG) } & Increase & 9 & 2.3 \\
\hline & decrease & 6 & 1.5 \\
\hline \multirow{2}{*}{$\begin{array}{l}\text { Low-density lipoprotein } \\
\text { (LDL) }\end{array}$} & Increase & 12 & 3.0 \\
\hline & decrease & 11 & 2.8 \\
\hline \multirow{2}{*}{$\begin{array}{l}\text { High-density lipoprotein } \\
\text { (HDL) }\end{array}$} & Increase & 5 & 1.3 \\
\hline & decrease & 9 & 2.3 \\
\hline
\end{tabular}

six $(1.5 \%)$ of the participants found that they had a decrease in triglycerides after using the protein supplements.

Only twelve (3.0\%) of our participants found that they had an increase in low-density lipoprotein, while eleven $(2.8 \%)$ of the participants found that they had a decrease in low-density lipoprotein after using the protein supplements.

Only five $(1.3 \%)$ of our participants found that they had an increase in high-density lipoprotein, while nine $(2.3 \%)$ of the participants found that they had a decrease in high-density lipoprotein after using the protein supplements.

\section{Relationship between practice and the change in lipid profile}

Table 11 demonstrates that there is no significant relationship between type of protein supplements and the change in lipid profile $\left(x^{2}=4.408, P=0.221\right)$. 
Table 11. Relationship between practice and the change in lipid profile $(n=71)$.

\begin{tabular}{l|c|c|c|c|c|}
\multicolumn{1}{|c|}{ Question } & \multicolumn{2}{|c|}{$\begin{array}{c}\text { change in } \\
\text { lipid profile }\end{array}$} & $\begin{array}{c}\text { Chi- } \\
\text { Square }\end{array}$ & Df & Sig. \\
\cline { 2 - 4 } & yes & No & $x^{2}$ & & \\
\hline What type of protein supplements do you use? & & \\
\hline Isolated whey protein & 17 & 26 & & & \\
\hline Concentrate whey protein & 5 & 4 & & & \\
\hline Collagen & 6 & 7 & 4.408 & 3 & 0.221 \\
\hline Other & 5 & 1 & & & \\
\hline
\end{tabular}

How many times do you use protein supplement per week?

\begin{tabular}{|l|c|c|c|c|c|}
\hline Daily & 13 & 23 & & \\
\hline four to six times & 13 & 5 & 6.543 & 2 & $0.038^{*}$ \\
\hline Once to three times & 7 & 10 & & & \\
\hline
\end{tabular}

How to use protein supplements?

\begin{tabular}{|c|c|c|c|c|c|}
\hline Correct & 14 & 25 & \multirow{2}{*}{3.895} & \multirow{2}{*}{1} & \multirow{2}{*}{$0.048 *$} \\
\hline Wrong & 19 & 13 & & & \\
\hline
\end{tabular}

How long have you been consuming your current protein supplement? \begin{tabular}{l|l|l}
$\geq 3-6$ months & 10 & 15
\end{tabular}

More than 6 months

Year

$2.107 \quad 3 \quad 0.550$

More than year

$7 \quad 5$

53

$\begin{array}{lll}2.107 & 3 & 0.550\end{array}$

Exercise intensity

Don't exercise

General fitness

Moderate

$11 \quad 15$

Strength

How much of water do you drink per day?

\begin{tabular}{|c|c|c|c|c|c|}
\hline $1-4$ cups & 6 & 12 & \multirow{4}{*}{14.193} & \multirow{4}{*}{3} & \multirow{4}{*}{$0.003^{* *}$} \\
\hline 4-6 cups & 19 & 6 & & & \\
\hline $6-8$ cups & 5 & 9 & & & \\
\hline More than 8 cups & 3 & 11 & & & \\
\hline
\end{tabular}

There is a significant relationship between the usage of protein per week and the change inlipid profile $\left(x^{2}=6.543, P=0.038\right)$.

There is a significant relationship between the method of protein consumption and the change inlipid profile $\left(x^{2}=3.895, P=0.048\right)$.
There is no significant relationship between the duration of protein consumption and the change inlipid profile $\left(x^{2}=2.107, P=0.550\right)$.

There is no significant relationship between Exercise intensity and the change inlipid profile $\left(x^{2}=\right.$ 5.479, $P=0.140$ ).

There is a significant relationship between the amount of water consumed per day and the change inlipid profile $\left(x^{2}=14.193, P=0.003\right)$ that means increase of water consumption per day improve lipid profile.

\section{Relationship between practice and the type of change in lipid profile}

Table 12 demonstrates that there is no significant relationship between practice of protein supplements and the type of change in lipid profile.

Table 12. Relationship between practice and the type of change in lipid profile $(n=33)$.

\begin{tabular}{|l|c|c|c|c|c|}
\hline \multicolumn{1}{|c|}{ Question } & \multicolumn{2}{c|}{$\begin{array}{c}\text { change in lipid } \\
\text { profile }\end{array}$} & $\begin{array}{c}\text { Chi- } \\
\text { Square }\end{array}$ & Df & Sig. \\
\cline { 2 - 5 } & Increase & decrease & $x^{2}$ & & \\
\hline What type of protein supplements do you use? & & & \\
\hline Isolated whey protein & 11 & 6 & & \\
Concentrate whey protein & 5 & 0 & 2.671 & 3 & 0.445 \\
\hline Collagen & 4 & 2 & & & \\
\hline Other & 4 & 1 & & & \\
\hline
\end{tabular}

How many times do you use protein supplement per week?

Daily

\begin{tabular}{|l|l|l|l|l|l|}
\hline four to six times & 9 & 4 & 1.864 & 2 & 0.394 \\
\hline Once to three times & 4 & 3 & & & \\
\hline
\end{tabular}

How to use protein supplements?

Correct

Wrong

\begin{tabular}{|l|l}
8 & 6 \\
16 & 3
\end{tabular}

2.977

0.084

How long have you been consuming your current protein supplement?

\begin{tabular}{|l|l|l|l|l|l|}
\hline$\geq 3-6$ months & 6 & 4 & & & \\
\hline More than 6 months & 5 & 2 & & & \\
\hline Year & 5 & 0 & 2.698 & 3 & 0.441 \\
\hline More than year & 8 & 3 & & & \\
\hline
\end{tabular}




\begin{tabular}{l|c|c|c|c|c|}
\hline \multicolumn{1}{|c|}{ Question } & $\begin{array}{c}\text { change in lipid } \\
\text { profile }\end{array}$ & $\begin{array}{c}\text { Chi- } \\
\text { Square }\end{array}$ & Df & Sig. \\
\cline { 2 - 4 } & Increase & decrease & $x^{2}$ & & \\
\hline Exercise intensity & & & & & \\
\hline Don't exercise & 9 & 2 & & & \\
\hline General fitness & 10 & 3 & 3.284 & 3 & 0.350 \\
\hline Moderate & 3 & 1 & & & \\
\hline Strength & 2 & 3 & & & \\
\hline How much of water do you drink per day? & & & \\
\hline 1-4 cups & 5 & 1 & & & \\
\hline 4-6 cups & 14 & 5 & 2.830 & 3 & 0.419 \\
\hline 6-8 cups & 4 & 1 & & & \\
\hline More than8 cups & 1 & 2 & & & \\
\hline
\end{tabular}

Table 13. Percentage of protein find in protein supplementssamples using kjeldhl method.

\begin{tabular}{|l|c|c|}
\hline \multirow{2}{*}{ Samples } & $\begin{array}{c}\text { Protein in } \\
\text { container label }\end{array}$ & Kjeldhl analysis \\
\cline { 2 - 3 } & $\%$ & $\%$ \\
\hline Isolated whey protein & 68.18 & 80.55 \\
\hline Concentrated whey protein & 72 & 77.2 \\
\hline Hydrolyzed collagen & 100 & 91.25 \\
\hline
\end{tabular}

\section{Percentage of protein found in protein supple- ments samples using Kjeldhl method}

Table 13 shows protein percentage in protein supplements products and by Kjeldhl analysis. The percentage of protein content in isolated whey protein (68.18\%) whiles by Kjeldhl analysis (80.55\%). Concentrated whey protein contain (72\%) and by kjeldhl analysis (77.2\%). Hydrolyzed collagen containing (100\%) protein and by kjeldhl analysis (91.25\%).

Table 14. Heavy metals determination in protein supplements samples using (ICP-MS).

\begin{tabular}{|l|c|c|c|c|}
\hline \multirow{2}{*}{ Samples } & Arsenic & Cadmium & Mercury & Lead \\
\cline { 2 - 5 } & $(\mu \mathrm{g} / \mathrm{L})$ & $(\mu \mathrm{g} / \mathrm{L})$ & $(\mu \mathrm{g} / \mathrm{L})$ & $(\mu \mathrm{g} / \mathrm{L})$ \\
\hline Isolated whey protein & 83 & 8.0 & $<10.0$ & 18.0 \\
\hline Hydrolyzed collagen & 101 & $<2.0$ & $<10.0$ & 49.0 \\
\hline
\end{tabular}

\section{Heavy metals determination in protein supple- ments samples using (ICP-MS)}

Table 14 shows the amount of heavy metals in (100gram) of protein supplements product samples. Isolated whey protein contains arsenic $(83 \mu \mathrm{g} / \mathrm{kg})$, cadmium $(8 \mu \mathrm{g} / \mathrm{kg})$, mercury $(<10 \mu \mathrm{g} / \mathrm{kg})$ and lead (18 $\mu \mathrm{g} / \mathrm{kg})$. Hydrolyzed collagen sample contains arsenic $(101 \mu \mathrm{g} / \mathrm{kg})$, cadmium $(<2 \mu \mathrm{g} / \mathrm{kg})$, mercury $(<10 \mu \mathrm{g} / \mathrm{kg})$ and lead $(49 \mu \mathrm{g} / \mathrm{kg})$.

\section{Discussion}

Protein supplements are one of the most frequently used dietary supplements used by athletes and nonathletes for performance enhancement and tissue repair $[3,4]$. It is divided into two sources plant protein (soy, bean and rice) or animal protein (milk, eggs and bovine colostrums) [9]. Protein supplements contain essential amino acids (EAA) like (lysine, leucine and methionine) and non-essential amino acids (NEAA) (glycine, proline, and alanine), hydroxy-proline is NEAA derivative formed through post translational protein modification during hydroxylation of proline [8].

Quality of protein sources is diverse according essential amino acids profile. Animal protein contains high amount of essential amino acids compared to plant protein, so it's classified as high quality protein. Additionally the quality of protein supplements products varies depending on the manufacturing process $[9,33]$.

In this study, the demographic characteristics of participants showed more than half of the participants (56.3\%) were in the age (21-30), while (32.9\%) of the participants were in the age (31-50) and $(10.3 \%)$ of the participants in the age (18-20) years. Previous studies found that most of participants were adolescent $[34,35,36]$. Also, in the present study we found that two-thirds of the participants females (60.1\%), while (39.9\%) of males participated. El Khoury and Antoine-Jonville (2012) found that the male users of protein supplements 
were more than females because they use it for muscle building and performance enhancement. Our study showed that, most of the participants had a bachelor's degree of (76.9\%) and (17.3\%) had Intermediate or high school while (5.8\%) had postgraduate studies [37].

Also, most of the participants (32.2\%) were in general fitness, twenty eight $(28.9 \%)$ did not perform exercise, twenty four (24.9\%) perform moderate exercise while fourteen (14.1\%) in perform strength exercise. More than half (55\%) of the participants used protein supplements for muscle building, while (30.9\%) were taking protein supplements for cosmetic and (14.1\%) were taking protein supplements for other purposes. In contrast, El Khoury and Antoine-Jonville (2012) found that most of participants use protein supplements for muscle building in high volume exercise intensity. These observations originate from misconceptions concerning effectiveness of protein supplement in muscle building without exercise or in general fitness [37].

In the current study, (46.7\%) of participants got protein supplements online, while (33.9\%) of participants got it through markets and (19.3\%) got protein supplements through pharmacies. The online purchase of protein supplements in this proportion of users may be exposed to the risk of using unregulated products with no formal test of their quality, especially from substandard retailers. And they increased education and awareness among protein supplements users as this poses a significant danger to their health is required [36].

We found that two hundred and forty-eight (71.4\%) of our participants did not know that the exceeding dose of protein supplements increase these side effect. Two hundred and thirty-two (58.3\%) of our participants knew that the protein supplements affect kidney. One hundred and seventeen (29.4\%) knew that the protein supplements affect lipid profile. In agreement with these findings El Khoury and Antoine-Jonville (2012) found that a majority of protein supplements users were unaware of the negative health implications when used in excess of the recommended dose. The high rate of consumption may be reflective or indicative of a pattern of dangerous and inappropriate use. Lack of adequate and proper knowledge explains the lack of awareness among users [37].

In the present study, majority of our participants (86\%) took protein supplements without advice doctor or pharmacist, while about (14\%) of the participants took protein supplements with taking advice. In agreements with our results, Jawadi et al., (2017) found that, users obtained their information regarding the use of supplements from coaches, online websites, journals and other sources which are mostly unreliable. Only $13.3 \%$ of participants took a physician's advice [14]. In contrast, Saudi study finding that reliable sources of information obtained from physicians (45.9\%) [38].

Our study showed that, the participants who consumed protein supplements in exceeding doseor in long durationaffect renal function especially for those who did not make exerciseor did not drink adequate amount of water. In agreement with So et al., (2016), who found that participants who consumed protein more and without physical activity were more likely to renal diseases [29]. High protein consumption causes dehydration which affects renal health [39]. Sontrop et al., (2013) found that, daily water intake more than two liters has protective effect on kidney [28].

Also, high protein consumption with light exercise intensity affects blood lipid profile but this effect is not clear and may be due to the lower number of participants who performed routine test on the lipid profile. Amini et al., (2016) found that, the disturbance in lipid profile due to fat contained in protein supplements products [30]. High exercise intensity is preventing this effect on lipid profile [19].

The percentage of protein content in isolated whey protein is $(68.18 \%)$, concentrated whey protein contain (72\%) and hydrolyzed collagen containing (100\%) protein. By Kjeldhl analysis, we 
found that isolated whey protein contain (80.55\%) of protein while concentrated whey protein contain $(77.2 \%)$ of protein hydrolyzed collagen containing $(91.25 \%)$. So, the percentage of protein content found by Kjeldhl analysis more than the percentage of protein content which labeled on containers. kjeldhl analysis showed that hydrolyzed collagen sample had a less protein percentage than container label. These is increase the potential risk of these products on renal function due to these effects on glomerular filtration rate and kidney stone formationrelated to increase in acid excretion and lower renal $\mathrm{PH}$; which is caused by calcium, oxalate and urea excretion it's a risk factor of chronic kidney disease [19, 21, 26, 39]. On other hand, some of supplements manufacturer reduce the amount of expensive components and added other components less cost [40].

The present study found that, in 100 grams of isolated whey protein contains arsenic $(83 \mu \mathrm{g} / \mathrm{kg})$, cadmium $(8 \mu \mathrm{g} / \mathrm{kg})$, mercury $(<10 \mu \mathrm{g} / \mathrm{kg})$ and lead $(18 \mu \mathrm{g} / \mathrm{kg})$, while hydrolyzed collagen sample contains arsenic $(101 \mu \mathrm{g} / \mathrm{kg})$, cadmium $(<2 \mu \mathrm{g} / \mathrm{kg})$, mercury $(<10 \mu \mathrm{g} / \mathrm{kg})$ and lead $(49 \mu \mathrm{g} / \mathrm{kg})$. Isolated whey protein sample contaminated with cadmium while hydrolyzed collagen sample contaminated with arsenic and lead. Heavy metals are highly toxic that they may have cumulative harmful effects especially to the kidneys and heart. The mechanism of heavy metals toxicity still unknown, although inhibition of enzymes, impaired antioxidants and make imbalance in redox system [12]. Arsenic, mercury and cadmium exposure affects the kidney by impaired proximal tubular cell function and glomerular damage $[12,41]$. Also, they cause adversely effect on blood lipid profile. Increased level of serum TG, TC, $\mathrm{LDL}$ and reduced $\mathrm{HDL}$ that is leads to atherosclerosis $[41,42]$. Lead exposure affects the mechanical and electrical cardiac activity and raise arterial pressure that develop cardiovascular disease [12].

\section{Conclusions}

The current study reveals an evidencefor lacking of the awareness, negative attitude and abuseof protein supplements, demonstrates necessity to further education regarding the use and purchasing of protein supplements to ensure the quality of these products. Additionally, abuse of protein supplements has an adverse effect on renal function and lipid profile.

The percentage of protein content found by Kjel$\mathrm{dhl}$ analysis is more than the percentage of protein content which labeled on containers and the samples contaminated with heavy metals which means that there are adulteration in the industry of protein supplements products, that is increased the harmful effects of the protein supplements on the renal function and blood lipid profile.

\section{Author Contributions}

All authors are contributing equally

\section{Conflict of Interest}

There is no conflict of interest

\section{Fund}

Self-funding

\section{References}

1. Thomson, C. A: Nutritional supplements in sports and exercise. JAMA. 2010; 303(18), 188-1869.

2. Bianco, A., Mammina, C., Paoli, A., Bellafiore, M., Battaglia, G., Caramazza, G. and Jemni, M: Protein supplementation in strength and conditioning adepts: knowledge, dietary behavior and practice in Palermo, Italy. Journal of the International Society of Sports Nutrition. 2011; 8(1), 25.

3. Pasiakos, S. M., Lieberman, H. R. and McLellan, T. M: Effects of protein supplements on muscle damage, soreness and recovery of muscle function and physical performance: a systematic review. Sports Medicine. 2014; 44, 655-670.

4. Haerinejad, M. J., Ostovar, A., Farzaneh, M. R. and Keshavarz, M: The prevalence and characteristics of performance-enhancing drug use among bodybuilding athletes in the south of Iran, Bushehr. Asian journal of sports medicine.2016; 7,35-45. 
5. Maughan, R. J: Quality Assurance Issues in the Use of Dietary Supplements, with Special Reference to Protein Supplements, 2. The Journal of nutrition. 2013; 143(11), 1843-1847.

6. Song, H. and Li, B: Beneficial effects of collagen hydrolysate: a review on recent developments. Biomed J Sci Technol Res. 2017;5, 1-4.

7. Flechsenhar, K. and McAlindon, T: Change in Serum Biomarkers in Patients with Osteoarthritis treated with Collagen Hydrolysate: Results of a Prospective Randomized Study. Journal of Arthritis.2016; 5, 219.

8. Phillips, S. M: Current Concepts and Unresolved Questions in Dietary Protein Requirements and Supplements in Adults. Frontiers in Nutrition.2017; 4(1), 1-7.

9. Naclerio, F., Alkhatib, A. and Jimenez, A: Effectiveness of whey protein supplement in resistance trained individuals. Journal of Sports Medicine \& Doping Studies. 2013; 3(3), 1-7.

10. Spendlove, J., Mitchell, L., Gifford, J., Hackett, D., Slater, G., Cobley, S. and O'Connor, H:Dietary intake of competitive bodybuilders. Sports Medicine.2015; 45, 1041-1063.

11. Pasiakos, S. M., Austin, K. G., Lieberman, H. R. and Askew, E. W: Efficacy and safety of protein supplements for US Armed Forces personnel: consensus statement. The Journal of nutrition. 2013; 143, 1811-1814

12. Alissa, E. and Ferns, G: Heavy Metal Poisoning and Cardiovascular Disease. Journal of Toxicology.2011; 5, 1-21.

13. Schwingshackl, L. and Hoffmann, G: Long-term effects of lowfat diet either low or high in protein on cardiovascular and metabolic risk factors: a systematic review and meta-analysis. Nutrition journal.2013; 12, 48.

14. Jawadi, A. H., Addar, A. M., Alazzam, A. S., Alrabieah, F. O., Al Alsheikh, A. S., Amer, R. R. and Badri, M: Prevalence of Dietary Supplements Use among Gymnasium Users. Journal of nutrition and metabolism. 2017; 17, 1-8.

15. Alnozha, O. and Elshatarat, R: Influence of Knowledge and Beliefs on Consumption of Performance Enhancing Agents in North-Western Saudi Arabia. Annals of Saudi Medicine.2017; 37(4), 317-325.

16. Phillips, S. M. and Van Loon, L. J: Dietary protein for athletes: from requirements to optimum adaptation. Journal of sports sciences. 2011; 29, 29-38.

17. Potgieter, S:Sport nutrition: A review of the latest guidelines for exercise and sport nutrition from the American College of Sport Nutrition, the International Olympic Committee and the International Society for Sports Nutrition. South African journal of clinical nutrition. 2013; 26(1), 6-16.

18. Porfírio, E. and Fanaro, G. B: Collagen supplementation as a complementary therapy for the prevention and treatment of osteoporosis and osteoarthritis: a systematic review. Revista Brasileira de Geriatria e Gerontologia. 2016; 19(1), 153-164.
19. Aparicio, V. A., Nebot, E., Porres, J. M., Ortega, F. B., Heredia, J. M., López-Jurado, M. and Ramírez, P. A: Effects of highwhey-protein intake and resistance training on renal, bone and metabolic parameters in rats. British Journal of Nutrition. 2011; 105(6), 836-845.

20. Helms, E. R., Aragon, A. A. and Fitschen, P. J: Evidence-based recommendations for natural bodybuilding contest preparation: nutrition and supplementation. Journal of the International Society of Sports Nutrition. 2014; 11, 20-33.

21. Aparicio, V. A., Nebot, E., Garcia-del Moral, R., MachadoVilchez, M., Porres, J. M., Sanchez, C., and Aranda, P: Highprotein diets and renal status in rats. Nutricion hospitalaria. 2013; 28(1), 232-236.

22. Schwingshackl, L. and Hoffmann, G: Comparison of high vs. normal/low protein diets on renal function in subjects without chronic kidney disease: a systematic review and meta-analysis. PloS one. 2014; 9(5), 956- 976.

23. Kateryna Goncharova, K., Rafał Filip, R., Paulina 『wieboda, P., Olena Prykhodko, O., Olexandr Fedkiv, O., Katarzyna Szwiec, K. and Grzegorz, S: Model Development of Hydroxyproline Induced Hyperoxaluria In Young Growing Pigs. European Journal of Clinical and Experimental Medicine.2017; 15(1), 6-11.

24. Ardalan, M., Samadifar, Z. and Vahedi, A: Creatine monohydrate supplement induced interstitial nephritis. Journal of nephropathology. 2012; 1(2), 117-120.

25. Nauffal, M and Gabardi, S: Nephrotoxicity of natural products. Blood purification. 2016; 41(1), 123-129.

36. Gao, S., Yang, R., Peng, Z., Lu, H., Li, N., Ding, J. and Dong, $X$ : Metabolomics analysis for hydroxy-L-proline-induced calcium oxalate nephrolithiasis in rats based on ultra-high performance liquid chromatography quadrupole time-of-flight mass spectrometry. Scientific reports. 2016; 6, 301- 42.

27. Peng, Li. and Guoyan, Wu: Roles of dietary glycine, proline, and hydroxyproline in collagen synthesis and animal growth. Amino acids. 2017; 7 , 1-10.

28. Sontrop, J. M., Dixon, S. N., Garg, A. X., Buendia-Jimenez, I., Dohein, O., Huang, S. H. S. and Clark, W. F: Association between water intake, chronic kidney disease, and cardiovascular disease: a cross-sectional analysis of NHANES data. American journal of nephrology. 2013; 37(5), 434-442.

29. So, R., Song, S., Lee, J. E. and Yoon, H. J: The Association between Renal Hyperfiltration and the Sources of Habitual Protein Intake and Dietary Acid Load in a General Population with Preserved Renal Function: The KoGES Study. PloS one. 2016; 11(11), 166- 195

30. Amini, P., Maghsoudi, Z., Feizi, A., Ghiasvand, R. and Askari, G: Effects of high protein and balanced diets on lipid profiles and inflammation biomarkers in obese and overweight women at aerobic clubs: A randomized clinical trial. International journal of preventive medicine.2016; 7,110. 
31. Cheungpasitporn, W., Rossetti, S., Friend, K., Erickson, S. B. and Lieske, J. C: Treatment effect, adherence, and safety of high fluid intake for the prevention of incident and recurrent kidney stones: a systematic review and meta-analysis. Journal of nephrology. 2016; 29(2), 211-219.

32. Horwitz, W. and Latimer, G. W., Jr: Official methods of analysis of AOAC International (18th ed.). Gaithersburg, Maryland, USA: AOAC International. 2005.

33. Landi, F., Calvani, R., Tosato, M., Martone, A. M., Ortolani, E., Savera, G. and Marzetti, E: Protein intake and muscle health in old age: from biological plausibility to clinical evidence. Nutrients. 2016; 8(5), 295

34. Tscholl, P., Alonso, J. M., Dollé, G., Junge, A. and Dvorak, J : The use of drugs and nutritional supplements in top-level track and field athletes. The American journal of sports medicine. 2010; 38(1), 133-140.

35. Diehl, K., Thiel, A., Zipfel, S., Mayer, J., Schnell, A. and Schneider, S: Elite adolescent athletes' use of dietary supplements: characteristics, opinions, and sources of supply and information. International journal of sport nutrition and exercise metabolism.2012; 22(3), 165-174.

36. Whitehouse, G. and Lawlis, T: Protein supplements and adolescent athletes: A pilot study investigating the risk knowledge, motivations and prevalence of use. Nutrition \& Dietetics. 2017; 74(5), 509-515.

37. El Khoury, D. and Antoine-Jonville, S: Intake of nutritional supplements among people exercising in gyms in beirut city. Journal of nutrition and metabolism. 2012; 8, 1-12.

38. Aljaloud, S. O. and Ibrahim, S. A: Use of dietary supplements among professional athletes in Saudi Arabia. Journal of nutrition and metabolism, 2013; 14, 1-7.
39. Tipton, K. D: Efficacy and consequences of very-high-protein diets for athletes and exercisers. Proceedings of the Nutrition Society. 2011; 70(2), 205-214.

40. Garrido, B. C., Souza, G. H., Lourenço, D. C. and Fasciotti, M: Proteomics in quality control: Whey protein-based supplements. Journal of proteomics. 2016; 147, 48-55.

41. Cheng, T. J., Chuu, J. J., Chang, C. Y., Tsai, W. C., Chen, K. J. and Guo, H. R: Atherosclerosis induced by arsenic in drinking water in rats through altering lipid metabolism. Toxicology and applied pharmacology. 2011; 256(2), 146-153.

42. Samarghandian, S., Azimi-Nezhad, M., Shabestari, M. M., Azad, F. J., Farkhondeh, T. and Bafandeh, F: Effect of chronic exposure to cadmium on serum lipid, lipoprotein and oxidative stress indices in male rats. Interdisciplinary toxicology. 2015; 8(3), 151154
Publish in International Archives of Medicine

International Archives of Medicine is an open access journal publishing articles encompassing all aspects of medical science and clinical practice. IAM is considered a megajournal with independent sections on all areas of medicine. IAM is a really international journal with authors and board members from all around the world. The journal is widely indexed and classified Q2 in category Medicine. 